Notes and Comments

\title{
Nocturnal ant integrates generalist pollination system in the Caatinga dry forest
}

\author{
A. Domingos-Melo ${ }^{a *}$ iD, T. L. Nadiab (iD, I. R. Lealc iD and I. C. Machado ${ }^{\mathrm{a}}$ iD \\ ${ }^{a}$ Universidade Federal de Pernambuco - UFPE, Centro de Biociências, Departamento de Botânica, Laboratório de Biologia Floral e Reprodutiva - \\ POLINIZAR, Recife, PE, Brasil \\ ' Universidade Federal de Pernambuco - UFPE, Centro Acadêmico de Vitória, Laboratório de Biodiversidade, Núcleo de Biologia, Vitória de Santo \\ Antão, PE, Brasil \\ ' Universidade Federal de Pernambuco - UFPE, Centro de Biociências, Departamento de Botânica, Laboratório de Interação Planta Aninal, Recife, PE, Brasil
}

Ant pollination is an uncommon system that has evolved independently in different Angiosperm families (Beattie, 2006). This interaction has been associated with arid environments because plants need produce fell floral resources and ants are ubiquitous in arid environments, even when other pollinators become scarce (DomingosMelo et al., 2017; Leal et al., 2017; Oliveira et al., 2017). Notwithstanding, many interactions between plants and ants in arid environments may shift to the night (e.g. herbivory or consumption of extrafloral nectar), likely due to the influence of climatic factors or in response to resource competition (Dattilo et al., 2014; Leal et al., 2017). This nocturnal condition likely extends to ant pollination. In fact, interactions with nocturnal vectors (e.g., bats, beetles, hawkmoths, small insects, and non-flying vertebrates) are important pollination strategy in dry environments, since nighttime interactions are not impeded by high temperatures and low humidity (Borges et al., 2016).

Recently, was described in two Ditassa species (Asclepiadoideae, Apocynaceae) a generalist pollination systems including groups as wasps, bees, flies and the first case ant pollination in the Caatinga (DomingosMelo et al., 2017). This dry forest in northeastern Brazil has low annual precipitation and a water deficit for most of the year, but there, ants are a highly diverse and conspicuous group (Machado et al., 1997); Leal et al., 2017; Oliveira et al., 2017). Despite the pollinator ants recorded at the time being diurnal, it is estimated that more than $22 \%$ of pollination systems in the Caatinga plant species are nocturnal (Machado and Lopes, 2004). In this context, new field records have revealed that Ditassa hastata Decne is visited by the nocturnal ant Camponotus pallescens (Mayr, 1887), Formicidae.

Many Camponotus species present nocturnal activity, which can be explained by self-regulation of the circadian rhythm of the colony itself and the availability of resources (Mildner and Roces, 2017). Additionally, its species are characterized by a vast food repertoire that includes the consumption of floral nectar, and some of them have been exceptionally registered as pollinators in some ecosystems, including a South African asclepiad, Eustegia minuta (Romero 2002; De Vega et al., 2009; Lach et al., 2010; Chirango et al. 2019; Del-Claro et al., 2019; Delnevo et al., 2020). Here, we report how the visitation frequency of Camponotus pallescens varies throughout the night and estimate its contribution to pollination.

The fieldwork was conducted in the Catimbau National Park $\left(8.61667^{\circ} \mathrm{S}, 37.15^{\circ} \mathrm{W}\right)$, Pernambuco, Brazil. There, the annual average temperature is $25^{\circ} \mathrm{C}$ and average rainfall is $1095.9 \mathrm{~mm}$ (Andrade et al., 2004). Most of the park has quartzolic sandy soils where individuals of Ditassa hastata can occur on sandstone outcrops (DomingosMelo et al., 2017). We performed focal observations during five consecutive nights from 17:30 to 2:30 (45 hours total). At each observation, we recorded the number of ants that visited flowers in 1-hour periods. We run a Kruskal-Wallis test with pairwise comparisons using Wilcoxon rank sum test to assess the differences in the frequency of visits between intervals. We measured each visit's duration $(n=60)$ and we randomly collected 73 ants to quantify the presence of attached pollinaria and pollinia.

At each visit, Camponotus pallescens travels on the branches of $D$. hastata searching for nectar in the flowers. Visit time was $61 \pm 56$ s, during which ants generally attempted to access all nectariferous chambers, accessing the mechanism of pollination with its front appendages (Figure 1A). We recorded a total of 205 visits ( $41 \pm 8$ visits per night). Ants arrived on the branches after 17:30h, but visits intensified only after 19:00h; as the night advances, ants reduce their activity, and visits become scarcer until stopping at 2:00h $\left(\chi^{2}=32.63 ; \mathrm{df}=8 ; \mathrm{p}<0.0001\right.$ - Figure $\left.1 \mathrm{~B}\right)$. This visit frequency, characterized by a few foraging individuals at nightfall followed by a substantial increase, aligns with the group recruitment common to the genus Camponotus (Lach, 2010). In this behavior, successful foraging recruits a group of several nestmates for the resource (Lach et al., 2010; Mildner and Roces, 2017).

In our sample, we recorded $8 \%$ of the $C$. pallescens individuals carrying pollinaria in their legs ( 6 individuals with one pollinarium each). Two of these pollinaria were

*e-mail: arthurdom.melo@gmail.com

Received: March 24, 2020 - Accepted: July 20, 2020

This is an Open Access article distributed under the terms of the Creative Commons Attribution License, which permits unrestricted use, distribution, and reproduction in any medium, provided the original work is properly cited. 


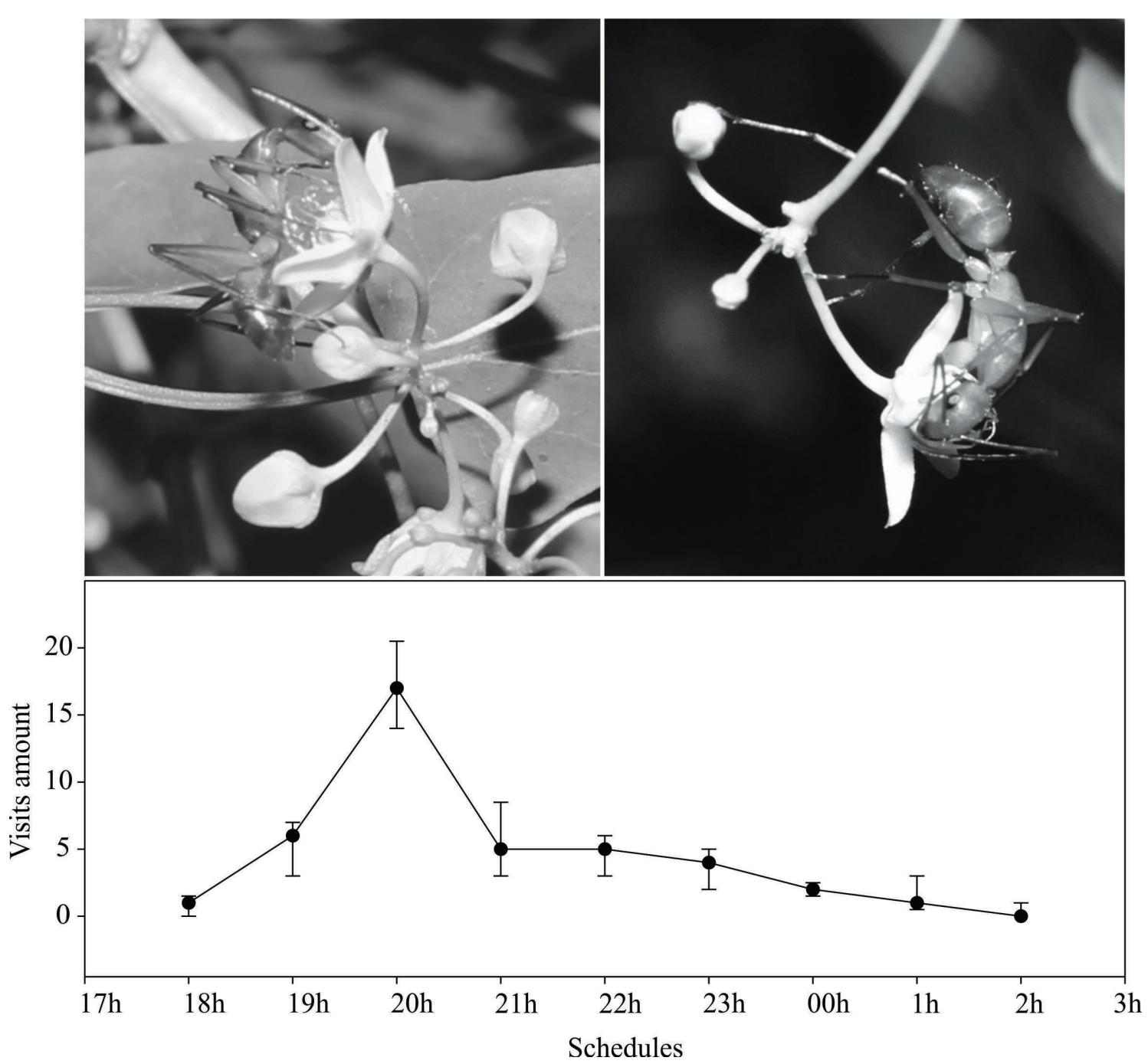

Figure 1. Visit behaviour of Camponotus pallescens on Ditassa hastata flowers in the Catimbau National Park, Pernambuco, Brazil. (A-B) C. pallescens taking nectar in different positions and (C) its visit frequency to D. hastata flowers throughout the night. (Black dots indicate median and error bars indicate first and third quartiles; Different letters indicate statistically significant difference from Kruskal-Wallis test with pairwise comparisons using Wilcoxon rank sum test with $\alpha=0.05$ )

complete with two polliniums; one had a single remaining pollinium, and three had no pollinia (suggesting that seven pollinia could have been deposited). Despite this small contribution of Camponotus pallescens as a pollinator for Ditassa hastata, it addresses the absence of other nocturnal pollinators in this species. Since in most asclepiads anthesis occurs both day and night, the contribution of nocturnal pollinators may be important (Bertin \& Willson, 1980; Domingos-Melo et al., 2019). In fact, even pollinators that play a secondary role in reproductive success are important for maintaining a species' resilience to environmental changes (Waser and Ollerton, 2006). The Caatinga is subject to climatic oscillations that can generate episodes of severe drought, resulting in ants' expanding their search for flowers (Santos et al., 2014; Leal et al. 2017). In this scenario, we understand that including nocturnal ants among the pollinator set could help increase pollination success.

\section{Acknowledgements}

This work was supported by: Conselho Nacional de Desenvolvimento Científico e Tecnológico (CNPq) through a scholarship granted to S.M.S.B. [14026498], and for the research grant [311021/2014-0] and partial financial support [459485/2014-8] conceded to I.C.M; I.R.L. also thanks CNPq for research grants (308300/2018-1). Fundação de Amparo à Ciência e Tecnologia do Estado de Pernambuco (FACEPE) for the scholarship awarded to A.D.M. [IBPG-0550-2.03/14]; and Coordenação de Aperfeiçoamento de Pessoal de Nível Superior - Brasil (CAPES) -Finance Code 001.

\section{References}

ANDRADE, K.V.S.A., RODAL, M.J.N., LUCENA, M.F.A. and GOMES, A.P.S., 2004. Composição florística de um trecho do Parque Nacional do Catimbau, Buíque, Pernambuco - Brasil. Hoehnea, vol. 31, no. 3, pp. 275-281. 
BEATTIE, A.J., 2006. The evolution of ant pollination systems. Botanische Jahrbücher, vol. 127, no. 1, pp. 43-55. http://dx.doi. org/10.1127/0006-8152/2006/0127-0043.

BERTIN, R.I. and WILLSON, M.F., 1980. Effectiveness of diurnal and nocturnal pollination of two milkweeds. Canadian Journal of Botany, vol. 58, no. 16, pp. 1744-1746. http://dx.doi.org/10.1139/ b80-202.

BORGES, R.M., SOMANATHAN, H. and KELBER, A., 2016. Patterns and processes in nocturnal and crepuscular pollination services. The Quarterly Review of Biology, vol. 91, no. 4, pp. 389-418. http:// dx.doi.org/10.1086/689481. PMid:29562117.

CHIRANGO, Y., STEENHUISEN, S.L., BRUYNS, P.V., MIDGLEY, J.J. and SHUTTLEWORTH, A., 2019. The March fly and the ant: the unusual pollination system of Eustegia minuta (Apocynaceae: Asclepiadoideae). Arthropod-Plant Interactions, vol. 3, no. 5, pp. 1-11. http://dx.doi.org/10.1007/s11829-019-09675-2.

DÁTTILO, W., FAGUNDES, R., GURKA, C.A., SILVA, M.S., VIEIRA, M.C., IZZO, T.J., DÍAZ-CASTELAZO, C., DEL-CLARO, K. and RICO-GRAY, V., 2014. Individual-based ant-plant networks: diurnal-nocturnal structure and species-area relationship. PLoS One, vol. 9, no. 6, pp. e99838. http://dx.doi.org/10.1371/journal.pone.0099838. PMid:24918750.

DE VEGA, C., ARISTA, M., ORTIZ, P.L., HERRERA, C.M. and TALAVERA, S., 2009. The ant-pollination system of Cytinus hypocistis (Cytinaceae), a Mediterranean root holoparasite. Annals of Botany, vol. 103, no. 7, pp. 1065-1075. http://dx.doi.org/10.1093/ aob/mcp049. PMid:19258337.

DEL-CLARO, K., RODRIGUEZ-MORALES, D., CALIXTO, E.S., MARTINS, A.S. and TOREZAN-SILINGARDI, H.M., 2019. Ant pollination of Paepalanthus lundii (Eriocaulaceae) in Brazilian savanna. Annals of Botany, vol. 123, no. 7, pp. 1159-1165. http://dx.doi. org/10.1093/aob/mcz021. PMid:30852596.

DELNEVO, N., VAN ETTEN, E.J., CLEMENTE, N., FOGU, L., PAVARANI, E., BYRNE, M. and STOCK, W.D., 2020. Pollen adaptation to ant pollination: a case study from the Proteaceae. Annals of Botany, vol. 126, no. 3, pp. 377-386. http://dx.doi.org/10.1093/aob/ mcaa058. PMid:32227077.

DOMINGOS-MELO, A., NADIA, T.L. and MACHADO, I.C., 2017. Complex flowers and rare pollinators: does ant pollination in Ditassa show a stable system in Asclepiadoideae (Apocynaceae)? Arthropod-Plant Interactions, vol. 11, no. 3, pp. 339-349. http:// dx.doi.org/10.1007/s11829-017-9499-3.
DOMINGOS-MELO, A., NADIA, T.L., WIEMER, A.P., COCUCCI, A.A. and MACHADO, I.C., 2019. Beyond taxonomy: anther skirt is a diagnostic character that provides specialized noctuid pollination in Marsdenia megalantha (AsclepiadoideaeApocynaceae). Plant Systematics and Evolution, vol. 305, no. 2, pp. 103-114. http://dx.doi.org/10.1007/s00606-018-1555-7.

LACH, L., PARR, C. and ABBOTT, K., 2010. Ant ecology. Oxford: Oxford University Press.

LEAL, I.R., RIBEIRO-NETO,J.D., ARNAN, X., OLIVEIRA, F.M.P., ARCOVERDE, G.B., FEITOSA, R.M. and ANDERSEN, A.N. 2017. Ants of the Caatinga: diversity, biogeography, and functional responses to anthropogenic disturbance and climate change. In: J. M. C. SILVA, I. R. LEAL and M. Tabarelli , eds. Caatinga the largest tropical dry forest region in South America. Cham: Springer International Publishing, pp. 65-95. http://dx.doi.org/10.1007/978-3-319-68339-3_3.

MACHADO, I.C. and LOPES, A.V., 2004. Floral traits and pollination systems in the Caatinga, a Brazilian tropical dry forest. Annals of Botany, vol. 94, no. 3, pp. 365-376. http://dx.doi.org/10.1093/ aob/mch152. PMid:15286010.

MACHADO, I.C., BARROS, L.M. and SAMPAIO, E.V., 1997. Phenology of Caatinga species at Serra Talhada, PE, northeastern Brazil. Biotropica, vol. 29, no. 1, pp. 57-68. http://dx.doi. org/10.1111/j.1744-7429.1997.tb00006.x.

MILDNER, S. and ROCES, F., 2017. Plasticity of daily behavioral rhythms in foragers and nurses of the ant Camponotus rufipes: influence of social context and feeding times. PLoS One, vol. 12, no. 1, pp. e0169244. http://dx.doi.org/10.1371/journal. pone.0169244. PMid:28099496.

OLIVEIRA, F.M.P., RIBEIRO-NETO, J.D., ANDERSEN, A.N. and LEAL, I.R., 2017. Chronic anthropogenic disturbance as a secondary driver of ant community structure: interactions with soil type in Brazilian Caatinga. Environmental Conservation, vol. 44, no. 2, pp. 115-123. http://dx.doi.org/10.1017/S0376892916000291.

ROMERO, G.Q., 2002. Protection of Vochysia elliptica (Vochysiaceae) by a nectar-thieving ant. Brazilian Journal of Biology $=$ Revista Brasileira de Biologia, vol. 62, no. 2, pp. 371-373. http://dx.doi. org/10.1590/S1519-69842002000200021. PMid:12489409.

SANTOS, G.M., DATTILO, W. and PRESLEY, S.J., 2014. The seasonal dynamic of ant-flower networks in a semi-arid tropical environment. Ecological Entomology, vol. 39, no. 6, pp. 674-683. http://dx.doi.org/10.1111/een.12138.

WASER, N.M. and OLLERTON,J., 2006. Plant-pollinator interactions: from specialization to generalization. Chicago: University of Chicago Press. 